\title{
Hepatocyte Growth Factor Regulates Migration of Olfactory Interneuron Precursors in the Rostral Migratory Stream through Met-Grb2 Coupling
}

\author{
Donatella Garzotto, ${ }^{1}$ Paolo Giacobini, ${ }^{1}$ Tiziana Crepaldi, ${ }^{2}$ Aldo Fasolo, ${ }^{1,3}$ and Silvia De Marchis ${ }^{1}$ \\ ${ }^{1}$ Department of Animal and Human Biology, University of Turin, 10123 Turin, Italy, ${ }^{2}$ Department of Anatomy, Pharmacology, and Forensic Medicine, \\ University of Turin, and ${ }^{3}$ National Institute of Neuroscience, 10125 Turin, Italy
}

\begin{abstract}
The olfactory bulb is one of the few structures in the mammalian forebrain in which continuous neurogenesis takes place throughout life. Neuronal precursors originate from progenitors located in the subventricular zone (SVZ) of the lateral ventricles, move tangentially in chains through the rostral migratory stream (RMS), and reach the olfactory bulb (OB), where they finally differentiate into granule and glomerular interneurons. Multiple molecular factors are involved in controlling the various steps of this neurogenic process. Here, we show that hepatocyte growth factor (HGF) and its receptor Met protein are expressed in vivo in the OB and throughout the migratory pathway, implying that HGF might mediate migratory signals in this system. By using primary in vitro cultures, we demonstrate that HGF promotes migration of RMS neuroblasts, acting both as an inducer and attractant. HGF stimulation on RMS tissue explants selectively induces MAP kinase pathway activation. Furthermore, in vitro analysis of mice with a point mutation in the Met receptor that impairs signal transduction through the Ras/MAP kinase pathway $\left(\mathrm{Met}^{\mathrm{Grb2/Grb2}}\right)$ shows that without Met-Grb2 binding, neuroblast migration is reduced. Overall, these findings indicate that HGF signaling via Met-Grb2 coupling influences olfactory interneuron precursor migration along the RMS.
\end{abstract}

Key words: cell migration; RMS; HGF; olfactory bulb; SVZ; Grb2

\section{Introduction}

The olfactory bulb (OB) of rodents is characterized by continuous neurogenesis throughout life. Neuronal precursors fated to become new $\mathrm{OB}$ interneurons originate outside the bulb, from progenitors located in the subventricular zone (SVZ) of the lateral ventricle. Before integrating into the $\mathrm{OB}$ circuits, neuronal precursors migrate tangentially from the SVZ to the $\mathrm{OB}$ in a complex network of chains, forming the rostral migratory stream (RMS) (Peretto et al., 1997, 1999). Once they have reached the OB core, single neuroblasts detach from their chains and switch from tangential to radial migration to populate the granule and glomerular layers, where they complete their differentiation (Luskin, 1993; Lois and Alvarez-Buylla, 1994). Migration of SVZderived neuroblasts is regulated by a cohort of molecular factors, including cell adhesion molecules, such as PSA-N-CAM (Tomasiewicz et al., 1993; Ono et al., 1994; Hu et al., 1996), and integrins (Murase and Horwitz, 2002), extracellular matrix molecules (e.g., tenascin-C, proteoglycans, and laminin) (Jankovski and Sotelo, 1996; Murase and Horwitz, 2002), and matrix metalloproteinases (Bovetti et al., 2007). Chemorepulsive mechanisms

Received Sept. 11, 2007; revised April 21, 2008; accepted April 22, 2008.

This work was supported by Compagnia di San Paolo (Neurotransplant 2004.2019), Regione Piemonte Ricerca Scientifica Applicata 2004 (project numbers A14 and A23), and Ricerca Finanziata Università di Torino 2007.

Correspondence should be addressed to Donatella Garzotto at the above address. E-mail: donatella.garzotto@unito.it.

DOI:10.1523/JNEUROSCI.1083-08.2008

Copyright $\odot 2008$ Society for Neuroscience $\quad$ 0270-6474/08/285901-09\$15.00/0 through Slit-Robo signaling (Wu et al., 1999) and chemoattractive cues, such as the secreted molecules netrin-1 (Murase and Horwitz, 2002), prokineticin2 (Ng et al., 2005), GDNF (Paratcha et al., 2006), and BDNF (Chiaramello et al., 2007) have been demonstrated to guide SVZ neuroblasts toward their target in the OB.

To further identify molecular factors involved in the control of neuroblasts migration in this system, we investigated the role of the hepatocyte growth factor (HGF; also known as scatter factor) and its tyrosine kinase receptor Met. HGF is a pleiotropic factor that plays an important function in a variety of developmental processes that involve cell migration, proliferation, and morphogenesis (Birchmeier and Gherardi, 1998). Both HGF and Met are expressed during brain development, and their transcripts have also been demonstrated in the adult brain, including the OB (Jung et al., 1994; Thewke and Seeds, 1996; Achim et al., 1997).

Converging evidence supports the notion that HGF acts as a chemoattractant for different neuronal cell types, such as motoneurons (Ebens et al., 1996), gonadotropin-releasing hormone (GnRH) cells (Giacobini et al., 2002), and striatal (Cacci et al., 2003) and cortical (Sun et al., 2002) progenitors. In addition, HGF is a motogen for interneuron precursors migrating from the ganglionic eminence to the cortex during embryonic brain development (Powell et al., 2001).

The possibility that HGF/Met signaling may play a regulatory role in the migration of olfactory interneuron precursors was 
explored by defining more precisely the expression pattern of Met and HGF along the SVZ-OB pathway as well as evaluating the effect of exogenous HGF on freshly dissociated neuroblasts and explants of the RMS cultured in vitro. We found that HGF induces both an increase in the migratory response and activation of ERK proteins, suggesting that it may regulate neuroblasts migration through the MAP kinase pathway. This hypothesis was confirmed by using $M e t^{G r b 2 / G r b 2}$ mutants, which have a point mutation in the Met receptor impairing signal transduction through the Ras/MAP kinase pathway (Maina et al., 1996). We conclude that HGF signaling via Met-Grb2 coupling is involved in the regulation of olfactory interneuron precursor migration.

\section{Materials and Methods}

Animals. Experiments were performed on newborn CD1 strain mice from postnatal day 5 (P5) to P10 (Charles River), kept in rooms with a lighting schedule of $12 \mathrm{~h}$ light/darkness and with standard diet and water ad libitum. Met ${ }^{G r b 2 / G r b 2}$ newborn (P0) mutant and wild-type (WT) background mice were provided by Prof. C. Ponzetto (Department of Anatomy, Pharmacology, and Forensic Medicine, Università degli studi di Torino, Torino, Italy). Postnatal mice were anesthetized by hypothermia for all experiments. All experimental procedures were in accordance with the European Communities Council Directive of November 24, 1986 (86/609/EEC) and the Italian law for care and use of experimental animals (DL116/92), and were approved by the Italian Ministry of Health and the Bioethical Committee of the University of Turin.

Tissue explants and GN11 cell line cultures. Tissue explant cultures were performed as previously described (Wichterle et al., 1997). Briefly, mice were anesthetized by hypothermia and then killed by rapid decapitation. Brains were dissected out and placed in ice-cold Leibovitz-15 medium (Invitrogen) and vibratome (Leica VT100S) cut into $250-\mu \mathrm{m}$-thick coronal slices in Leibovitz-15 medium. Tissues from SVZ and RMS were isolated under a high-magnification dissecting microscope (Leica) and trimmed into pieces of $\sim 250 \mu \mathrm{m}$. Explants were subsequently embedded in 75\% Matrigel growth factor reduced (BD Biosciences). Explants were maintained $1 \mathrm{~d}$ in vitro ( $1 \mathrm{DIV}$ ) in $5 \% \mathrm{CO}_{2}$ at $37^{\circ} \mathrm{C}$ in Neurobasal medium (Invitrogen) supplemented with $1 \times \mathrm{N}-2$ (Invitrogen), $25 \mu \mathrm{g} / \mathrm{ml}$ gentamicin (Invitrogen), and $0.5 \mathrm{~mm}$ glutamine (Invitrogen). Recombinant human HGF (50 ng/ml) (Sigma-Aldrich) and/or $10 \mu \mathrm{g} / \mathrm{ml}$ neutralizing antibody anti-HGF (\#AF-294-NA; R \& D Systems) were mixed into Matrigel gel and added to culture media. For analysis, tissue explants were fixed in $4 \%$ paraformaldehyde (PFA) for $40 \mathrm{~min}$ and stained with nuclear marker SYTOX Green (167 nM; Invitrogen) for $30 \mathrm{~min}$ at room temperature. Some explants were processed for immunocytochemistry as described in the following sections. For Western blot analysis, tissue explants immediately after dissection were incubated for $20 \mathrm{~min}$ at $37^{\circ} \mathrm{C}$ in Neurobasal medium with or without HGF $(50 \mathrm{ng} / \mathrm{ml})$. Inhibition of the MAP kinases was obtained by incubating the explants with $50 \mu \mathrm{M}$ 2-(2-amino-3-methyoxyphenyl)-4H-1-benzopyran-4-one (PD98059) (Sigma-Aldrich), $1 \mathrm{~h}$ before and during HGF stimulation. After stimulation, explants were rinsed twice in cold PBS, pH 7.4, containing $1 \mathrm{~mm}$ sodium-orthovanadate.

GN11 cells were grown in monolayer at $37^{\circ} \mathrm{C}$ in a $5 \% \mathrm{CO}_{2}$, in DMEM (Invitrogen) containing $1 \mathrm{~mm}$ sodium pyruvate, $2 \mathrm{~mm}$ glutamine (Invitrogen), $100 \mu \mathrm{g} / \mathrm{ml}$ streptomycin, $100 \mathrm{U} / \mathrm{ml}$ penicillin, and $4500 \mathrm{mg}$ of glucose (Invitrogen), and supplemented with 10\% fetal bovine serum (FBS; Invitrogen). For stimulation assay, GN11 cells were grown at subconfluence and starved overnight in DMEM in absence of FBS. The day after, cells were treated for 15 min with medium containing 10 or 50 $\mathrm{ng} / \mathrm{ml} \mathrm{HGF}$ or conditioned medium collected from cultures of RMS and SVZ at 1 DIV.

Boyden assay. Boyden membranes ( $5 \mu \mathrm{m}$; Neuro Probe) were precoated on both sides with $30 \mu \mathrm{g} / \mathrm{ml}$ poly-D-lysine (Sigma-Aldrich) overnight. Anterior RMS (aRMS) of P5-P10 mice was dissected from coronal sections of the $\mathrm{OB}$, as described in the previous section, and incubated in $250 \mu \mathrm{l}$ of $25 \%$ trypsin-EDTA (Invitrogen) at $37^{\circ} \mathrm{C}$ for $5 \mathrm{~min}$. Tissue was then triturated, and trypsin activity was blocked in 20\% FBS in Neurobasal (Invitrogen), to obtain a single-cell suspension. Cells were spun for
$7 \mathrm{~min}$ at $3400 \mathrm{rpm}$ and resuspended in Neurobasal medium supplemented with N2. Cells were incubated in $5 \% \mathrm{CO}_{2}$ at $37^{\circ} \mathrm{C}$ for $2 \mathrm{~h}$ before migration assays. Fifty thousand cells were placed in the Boyden apparatus upper chamber, and increasing concentrations of $\operatorname{HGF}(12.5,25,50$, and $100 \mathrm{ng} / \mathrm{ml}$ ) were added to the lower chamber. Medium containing 50 $\mathrm{ng} / \mathrm{ml} \mathrm{HGF}$ was preincubated for neutralizing studies, with $10 \mu \mathrm{g} / \mathrm{ml}$ anti-HGF antibody overnight. The Boyden chamber was kept in a cell culture incubator in $5 \% \mathrm{CO}_{2}$ at $37^{\circ} \mathrm{C}$ for $24 \mathrm{~h}$. The membrane was subsequently fixed in $4 \%$ PFA and rinsed in $0.01 \mathrm{M}$ PBS. The upper side of the membrane was wiped out, and the cells that had migrated and attached to the lower side were stained by incubation with nuclear-staining $4^{\prime}, 6^{\prime}$ diamidino-2-phenylindole (DAPI) for $20 \mathrm{~min}$ at room temperature. For each well, DAPI images were taken of four random objective fields using an Olympus IX50 inverted microscope (Olympus Optical) equipped with a CCD camera CoolSNAP-Pro (Media Cybernetics), and images were edited with Image-Pro Plus software (Media Cybernetics). The mean number of migrating cells per square millimeter was calculated and normalized to controls for each condition. Neuronal phenotype of DAPI-positive cells was evaluated by immunofluorescence using anti$\beta$ III-tubulin antibody (Sigma-Aldrich).

Reverse transcription-PCR. Expression of HGF, Met, and L-19 was analyzed by reverse transcription (RT)-PCR. Total RNA was isolated from aRMS, posterior RMS (pRMS), SVZ, and total OB of P5 mice using Qiagen columns according to the manufacturer's instructions. Five hundred nanograms of total RNA were reverse transcribed into single stranded cDNA in a volume of $20 \mu \mathrm{l}$ using $200 \mathrm{U}$ of M-MLV ReverseTranscriptase RNaseH (Invitrogen) in $1 \times$ buffer (Invitrogen) with 25 $\mu \mathrm{g} / \mathrm{ml}$ oligo(dT) ${ }_{12-18}$ (Invitrogen), $0.5 \mathrm{~mm}$ dNTPs (Invitrogen), $0.01 \mathrm{M}$ DTT(Invitrogen), and $2 \mathrm{U} / \mu \mathrm{l}$ RNaseOUT (Invitrogen). An enzymeless reaction was performed for each sample as a control. PCRs were performed in a total volume of $50 \mu \mathrm{l}$ containing $2 \mu \mathrm{l}$ of cDNA, enzymeless reaction sample, or water (negative controls), $250 \mathrm{~nm}$ each $5^{\prime}$ - and $3^{\prime}$ primers (see below), $0.05 \mathrm{U} / \mu \mathrm{l}$ RED Taq DNA polymerase (SigmaAldrich), $200 \mu \mathrm{M}$ dNTPs in $1 \times$ buffer. The following primers were used: 5'-GGGACTGCAGCAGCAAAGC-3' and 5'-GTCTGAGCATCTAGAGTTTCC-3' for Met amplification, corresponding to nucleotides 296-815 (Chan et al., 1988); 5' -GGGGAATGAGAAATGCAGTCAG-3' and 5'-CCTGTATCCATGGATGCTTC-3' for HGF amplification, corresponding to nucleotides 1981-2275 (Tashiro et al., 1990); and 5' CCTGAAGGTCAAAGGGAATGTGTTC-3' and 5'-GGACAGAGTCTTGATGATCTCCTCC-3' for L-19 amplification, corresponding to nucleotides 400-595 (gi56971151). Number of cycles and annealing temperature used for all primer pairs were 35 cycles and $55^{\circ} \mathrm{C}$. Amplification products were separated by $2 \%$ agarose gel (Sigma-Aldrich) electrophoresis and DNA bands visualized by ethidium bromide staining.

Western blotting. GN11 cells were rinsed twice with cold PBS containing $1 \mathrm{~mm}$ sodium-orthovanadate and protein extracted with cold RIPA buffer (50 mm Tris-HCl, pH 7.4, 1\% NP-40, 0.25\% Na-deoxycholate, 150 mм NaCl, 1 mм EDTA, 1 mм PMSF, 1 mм $\mathrm{Na}_{3} \mathrm{VO}_{4}, 1 \mathrm{~mm} \mathrm{NaF}, 1 \mathrm{~mm}$ aprotinin, $1 \mathrm{~mm}$ leupeptin, and $1 \mathrm{~mm}$ pepstatin) for $20 \mathrm{~min}$ on ice. Extracts were spun at 14,000 rpm for $10 \mathrm{~min}$, and supernatants were collected in new test tubes.

Whole OBs and tissue explants were solubilized in boiling lysis buffer (50\% Tris-HCl, pH 6.8, 2.5\% SDS).

Protein quantification was performed by a bicinchoninic acid kit (Sigma-Aldrich). Equal amounts of total proteins were denatured by boiling in Laemmli buffer (2\% SDS, 50 mu Tris-HCl, pH 7.4, 20\% mercaptoethanol, and $20 \%$ glycerol) and subjected to $8 \%$ SDS-PAGE. Proteins were blotted onto Hybond-C Extra membrane (GE Healthcare). After blocking with 5\% powder milk in TBST buffer (20 mM Tris, $150 \mathrm{~mm}$ $\mathrm{NaCl}$, and $0.1 \%$ Tween $20, \mathrm{pH} 7.4$ ), filters were probed with 1:1000 rabbit anti-phospho-Met (P-Met; Cell Signaling Technology), 1:500 mouse anti-Met (SCB2; Santa Cruz Biotechnology), 1:1000 rabbit anti-Met (SC162; Santa Cruz Biotechnology), 1:500 goat anti-HGF (R \& D Systems), 1:30,000 mouse anti- $\alpha$-actin (Sigma-Aldrich), 1:200 rabbit antiphospho-Akt (Cell Signaling Technology), 1:1000 mouse anti-Akt (Cell Signaling Technology), 1:1000 mouse anti-phospho-ERKs (Cell Signaling Technology), and 1:1000 rabbit anti-ERKs (Cell Signaling Technology). After rinsing in TBST buffer, membranes were probed with HRP- 
A

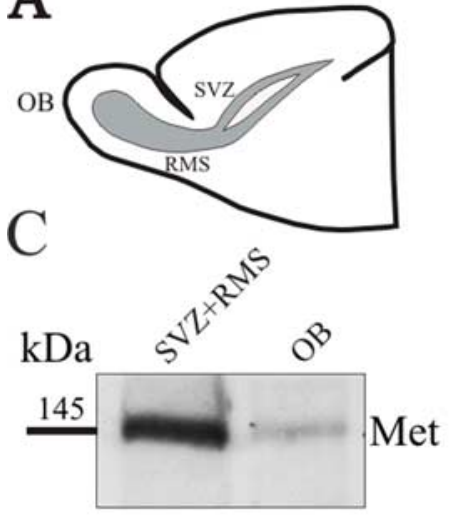

B
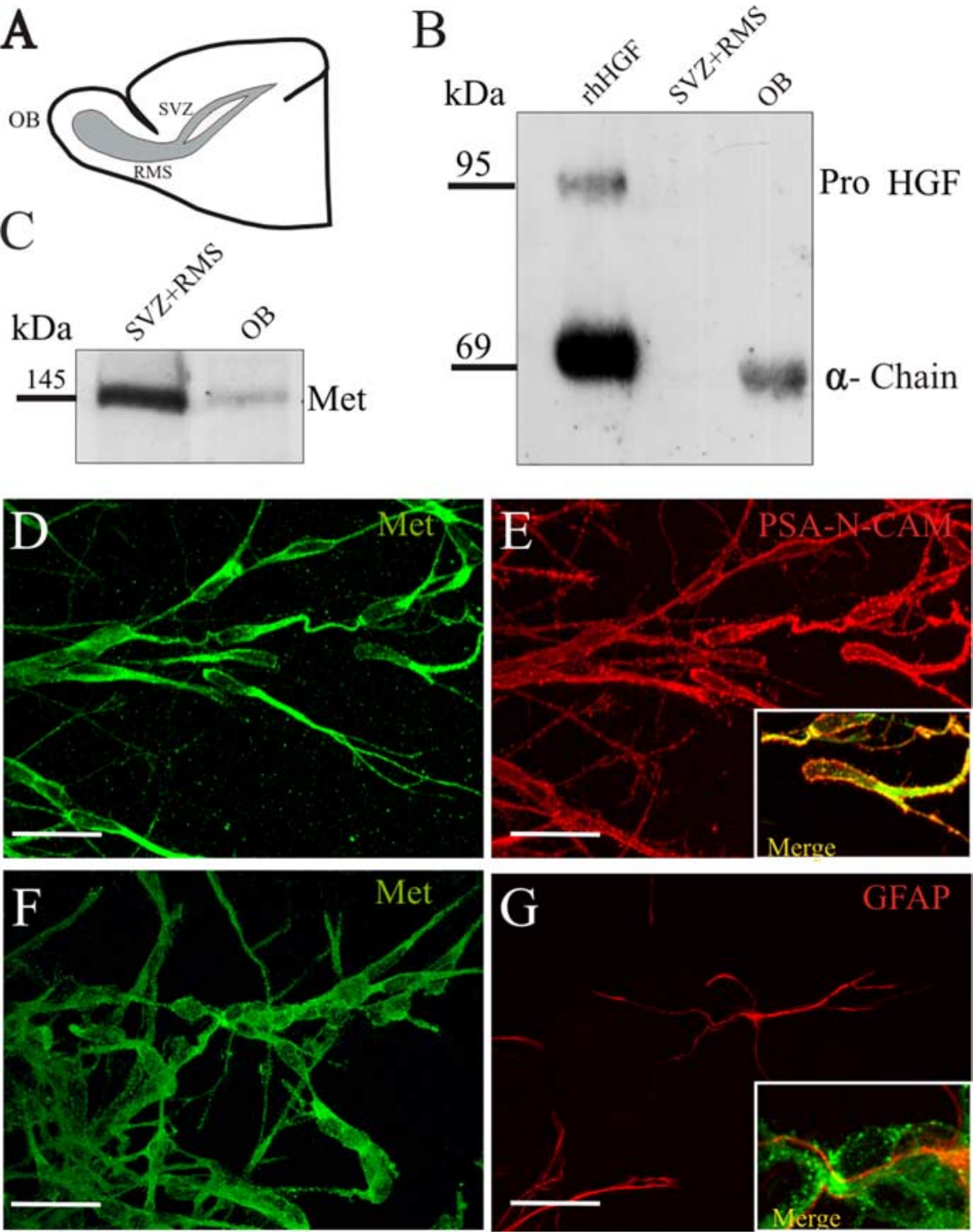

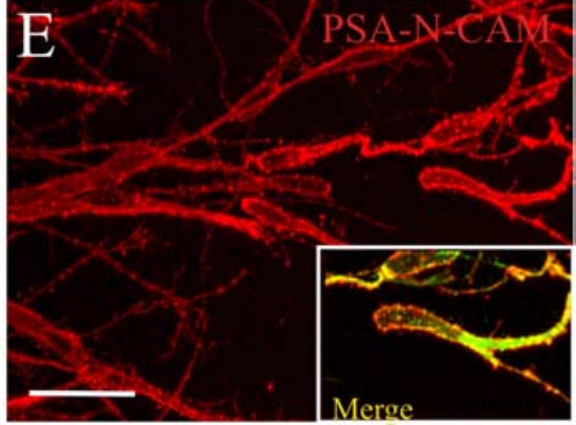

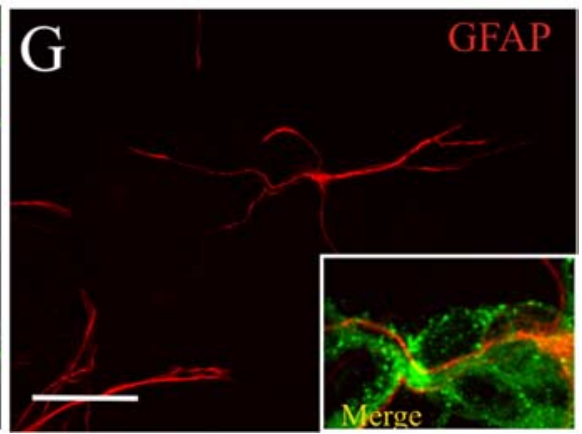

Figure 1. HGF and Met expression in the SVZ-OB system of the postnatal mice. $\boldsymbol{A}$, Schematic representation of a sagittal forebrain slice of P5 mice. $B, C$, Western blot analyses were performed on tissue explants isolated from the RMS and SVZ portions of the SVZ-OB system (in gray) and whole OB. $B$, By using recombinant human HGF (rhHGF), a 95 kDa band corresponding to the pro-HGF protein and a $69 \mathrm{kDa}$ band corresponding to the mature $\alpha$ chain were detected. Extracts obtained from the whole $0 \mathrm{~B}$ express the biologically functional $69 \mathrm{kDa}$ form. No signal was detected in the SVZ+RMS lane. C, A $145 \mathrm{kDa}$ band corresponding to Met receptor was found in the $0 B$ and in the SVZ+RMS. D,F, At 1 DIV, cells that migrated out of RMS tissue explant are positive for Met. $\boldsymbol{D}, \boldsymbol{E}$, Double PSA-N-CAM/Met immunostaining shows colocalization ( $\boldsymbol{E}$, inset). $\boldsymbol{F}, \boldsymbol{G}$, Double GFAP/Met immunostaining shows no colocalization (G, inset). Scale bars: $\boldsymbol{D}-\mathbf{G}, 50 \mu \mathrm{m}$.

conjugated secondary antibodies: 1:10,000 anti-rabbit (Abcam), 1:10,000 anti-mouse (Abcam), and 1: 30,000 anti-goat (Abcam), and revealed with West-Pico ECL method (Pierce Biotechnology). After film scanning, densitometric bands analyses were performed with Quantity One software (Bio-Rad Laboratories).

Immunofluorescence. After rinsing in PBS, explants were incubated 24 or $48 \mathrm{~h}$ at $4^{\circ} \mathrm{C}$ with primary antibodies diluted in $0.01 \mathrm{M} \mathrm{PBS,} 0.5 \%$ Triton $\mathrm{X}-100$, and $1 \%$ normal serum from the same species of secondary antibodies. Primary antibodies used were as follows: 1:100 rabbit anti-Met (H-190; Santa Cruz Biotechnology), 1:2500 mouse anti-PSA-N-CAM (AbCys), 1:1000 mouse anti-GFAP (Roche Diagnostics), 1:400 mouse anti- $\beta$ III-tubulin (Sigma-Aldrich), 1:1500 goat anti-doublecortin (Santa Cruz Biotechnology), 1:1000 rabbit anti-Ki67 (Novocastra Laboratories), 1:100 rabbit anti-phospho-histone 3 (PH3; Millipore), and 1:3000 rabbit anti-cleaved caspase-3 (Cell Signaling Technology). After rinsing in PBS, samples were incubated $1 \mathrm{~h}$ at room temperature with the following secondary antibodies diluted in 0.01 M PBS: 1:250 biotinylated goat

anti-rabbit (Vector Laboratories) followed by 1:400 avidin-FITC (Vector Laboratories), 1:800 goat anti-mouse Cy3 (Vector Laboratories) and 1:250 biotinylated horse anti-goat (Vector Laboratories).

Photography and data analysis. All tissue explant images were captured on a Fluo-View 200 confocal microscope (Olympus Instruments). Quantification of cell migration from the explants was performed on SYTOX Green-labeled specimens (at least 19 explants for each treatment). The migration area was evaluated on digitalized images as the surface covered by SYTOX Green nuclear staining excluding the tissue explant area. Migrating cell distribution was determined on multistack confocal images spaced at $5 \mu \mathrm{m}$. A grid of three squares of $10^{4}$ $\mu \mathrm{m}^{2}$ was overlaid on digitalized images starting from the main tissue edge (see Fig. $3 G$, schematic). The total number of SYTOX Greenstained nuclei was calculated for each square by using NIH ImageJ software. Cell proliferation was evaluated by counting all Ki67- or PH3immunopositive cells in the tissue explants (at least nine explants for each condition) using ImageJ software or Neurolucida (MBF Bioscience), respectively. Cell apoptotic death in tissue explants was evaluated counting the number of cleaved-caspase-3-immunopositive cells by the plugin "Analyze particles" of ImageJ software. Statistical analyses performed using SPSS software were applied according to the different cases and are indicated in Results.

\section{Results}

HGF expression and Met localization in the SVZ-OB system

Although the presence of HGF along the RMS and of HGF and Met in postnatal and adult mice OB had previously been demonstrated by in situ hybridization studies (Honda et al., 1995; Thewke and Seeds, 1996; Achim et al., 1997), no data on their protein expression and localization in the SVZ-OB system had been reported. To address this point, we first analyzed by Western blot HGF and Met expression in tissue extracts obtained from the SVZ of the lateral ventricle and RMS (SVZ+RMS), as well as from the whole OB (Fig. $1 A-C$ ). HGF is initially biosynthesized and secreted in a biologically inactive single-chain form (pro-HGF; $\sim 100 \mathrm{kDa}$ ) and is subsequently activated by specific serine proteases into $\alpha$-chain $(69 \mathrm{kDa})$ and $\beta$-chain $(34 \mathrm{kDa})$ forms (Tashiro et al., 1990; Hara et al., 1993). Blots incubated with anti-HGF antibody showed a band corresponding to the 69 $\mathrm{kDa} \alpha$-chain, indicating that HGF protein is present in an activated form in the $\mathrm{OB}$. In contrast, no signal could be detected for HGF in SVZ+RMS extracts (Fig. $1 B$ ). Western blot analysis revealed a $145 \mathrm{kDa}$ band, corresponding to Met in SVZ+RMS and whole $O B$ extracts, although at different intensities, with a higher signal in SVZ+RMS extracts (Fig. 1C). The SVZ and RMS are made up of different cell types, including astrocytes, stem cells, highly proliferating progenitors, and migrating precursors (Alvarez-Buylla and Garcia-Verdugo, 2002). Immunohistochemical analysis was performed to distinguish which cell types 
express Met. Specific Met antibodies failed to provide sufficient sensitivity in vivo; thus, the in vitro model of tissue explants cultured in a Matrigel three-dimensional matrix (Wichterle et al., 1997) was adopted. When SVZ or RMS explants are thereby cultured for $24 \mathrm{~h}$, compact chains of PSA-N-CAM-positive migrating neuroblasts are symmetrically distributed around the explant, whereas GFAPpositive astrocytes appear to be mainly localized in the explant core (supplemental Fig. 1, available at www.jneurosci.org as supplemental material) (Wichterle et al., 1997). By using the anti-Met antibody, we found that $100 \%$ of cells migrating out of the explant were immunopositive (supplemental Fig. 2, available at www. jneurosci.org as supplemental material). Accordingly, double-immunolabeling reactions using anti-Met combined with anti-PSA-N-CAM showed that all PSA-NCAM-positive cells were double labeled for Met (Fig. 1D,E), whereas no colocalization was found using anti-GFAP antibody (Fig. $1 F, G$ ), indicating that the Met receptor is expressed by migrating neuroblasts.

HGF/Met signaling is activated in the SVZ and along the RMS To evaluate whether HGF/Met signaling is activated in vivo in the SVZ and along the RMS, Western blot was used to analyze Met phosphorylation on tissue microdissections obtained from three different levels of the system: the SVZ of the lateral ventricle, the pRMS, corresponding to the RMS vertical arm, and the aRMS, corresponding to the RMS rostral extension in the OB (Fig. 2A) (Paratcha et al., 2006). Although Met expression is higher in the most posterior regions compared with more rostral ones, we found the P-Met/Met ratio to be comparable (arbitrary units: aRMS, 102.3; pRMS, 104.3; SVZ, 103.7) (Fig. 2B,C), suggesting HGF presence and activity all along the system. This growth factor can either reach the RMS and SVZ by diffusion from the OB, where it is expressed in an active form (Fig. $1 B$ ), or be synthesized locally. Classical Western blot analysis failed to demonstrate HGF expression in the SVZ+RMS extracts; however, qualitative RT-PCR analysis (Fig. 2 B), according to previous in situ hybridization data (Thewke and Seeds, 1996), indicates that HGF mRNA is expressed in these regions. Hence, as an alternative approach for testing whether these portions of the SVZ-OB system are able to produce and release functional HGF, culture media conditioned by SVZ or aRMS tissue explants were collected and used for Met activation studies on GN11 immortalized GnRH neurons (Radovick et al., 1991). HGF stimulation on GN11 cells had previously been demonstrated to induce Met phosphorylation (Giacobini et al., 2002). In our experiments, GN11 cells in serum-free conditions were stimulated for $15 \mathrm{~min}$ with medium containing 10 or $50 \mathrm{ng} / \mathrm{ml} \mathrm{HGF}$ (as positive controls) or with media conditioned by either SVZ or aRMS for $24 \mathrm{~h}$ and analyzed by Western blot using Met and P-Met antibodies. We confirmed that HGF induces Met phosphorylation in GN11 cells in a concentration-dependent manner (Fig. 2D). In addition, we showed that GN11 cell incubation with either SVZ- or aRMS-conditioned media leads to Met phosphorylation (Fig.
B

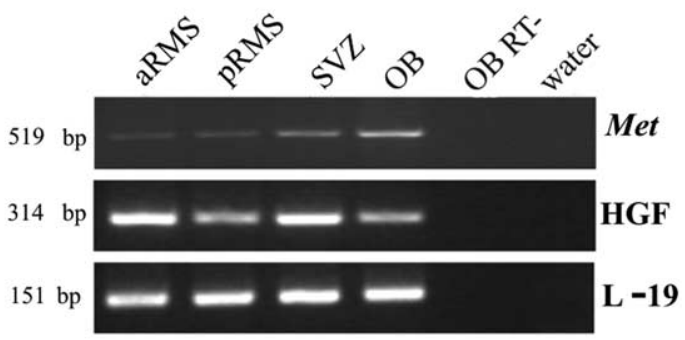

$\mathrm{D}$

\section{(1)}

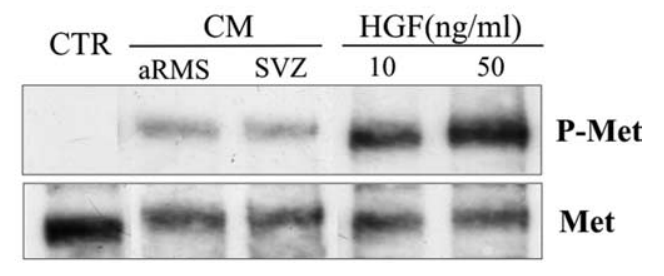

Figure 2. HGF-Met signaling is activated in the SVZ and along the RMS. $\boldsymbol{A}$, Schematic representation of a sagittal forebrain slice P.MA wa $\alpha$-Actin
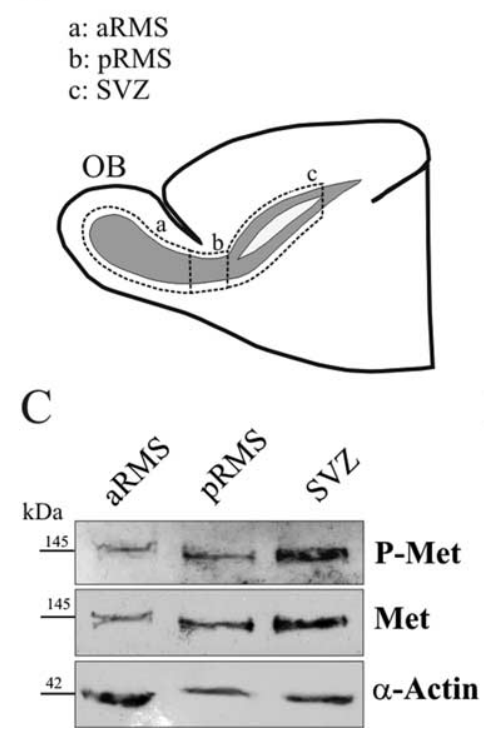

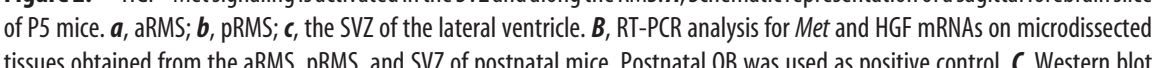
analysis for Met and P-Met. D, $\alpha$-Actin bands were used to normalize Western blot on extracts derived from GN11 cell line stimulated with HGF (10 and $50 \mathrm{ng} / \mathrm{ml}$ ) or with conditioned media from 1 DIV aRMS and SVZ explants. The experiment was repeated twice with similar results.

$2 D)$, supporting the hypothesis that functionally active HGF is produced and released in a bioactive form in the SVZ and along the RMS. In control conditions, no signal was detectable for P-Met (Fig. 2D).

\section{Exogenous HGF does not induce cell proliferation and survival on SVZ and RMS explants cultured in vitro} Activated HGF/Met signaling in the SVZ and along the RMS suggests that this factor can play multiple roles in the SVZ-OB system, including modulation of cell proliferation, survival, and migration. To verify these activities, we treated SVZ+RMS tissue explants with exogenous HGF (Fig. 3). When freshly dissected explants were stimulated for 20 min with recombinant HGF (50 $\mathrm{ng} / \mathrm{ml}$ ), a 2.5-fold increase in Met phosphorylation was observed, indicating that neuroblasts respond to exogenous HGF, activating Met receptor (Fig. 3A). Proliferative activity was analyzed on SVZ and aRMS tissue explants cultured in Matrigel, in the presence or absence of HGF (50 ng/ml). At 6 and $24 \mathrm{~h}$ after plating, the total number of nuclei immunopositive for $\mathrm{PH} 3$, a specific marker for the mitotic phase of the cell cycle (Estivill-Torrus et al., 2002), was counted. As in previous observations (Chiaramello et al., 2007), we found mitotic cells mainly in the tissue explant core (data not shown). In vivo, the SVZ of the lateral ventricle is enriched by proliferating progenitors, whereas the RMS contains a reduced number of proliferating cells (Gritti et al., 2002). Similarly, in vitro, the density of mitotic cells was significantly higher in SVZ than in aRMS $(p<0.01)$ (Fig. 3B). In both SVZ and aRMS explants, the number of $\mathrm{PH} 3$-positive cells decreases with time $(p<0.01)$ (Fig. 3B), but no differences were detected between control (CTR) and HGF-stimulated explants (Fig. 3B). Because the $\mathrm{PH} 3$ antigen is expressed selectively by cells in the mitotic phase, to extend the analysis we used another proliferation marker, Ki67, which is expressed during all active phases of the cell cycle (Wojtowicz and Kee, 2006). As for PH3, at 1 DIV, the density of Ki67-positive cells was significantly higher in the 


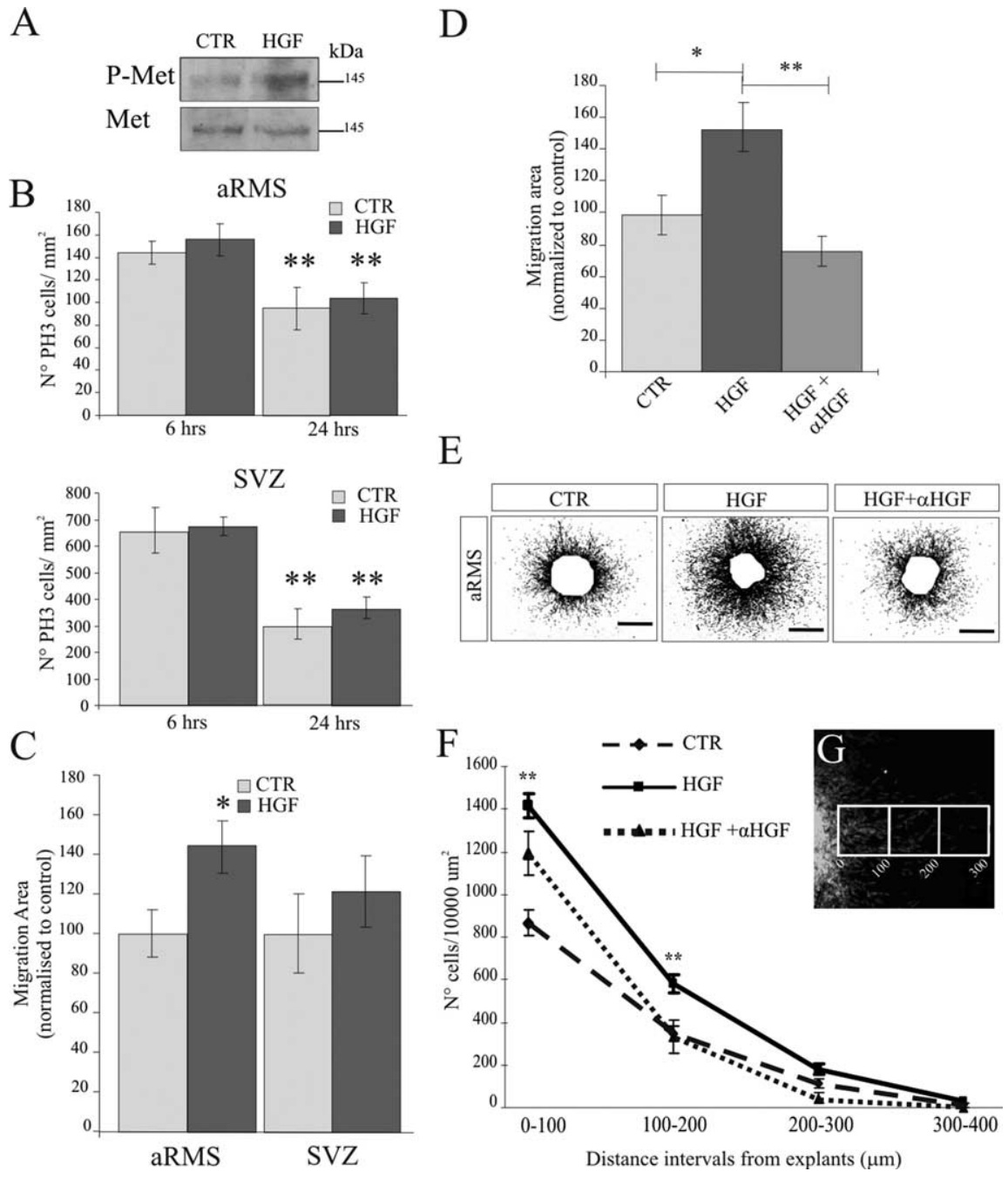

Figure 3. HGF promotes RMS neuroblast motility. $\boldsymbol{A}$, Western blot analysis for Met and P-Met in CTR and after 20 min of HGF (50 $\mathrm{ng} / \mathrm{ml}$ ) stimulation on SVZ+RMS tissue extracts. $\boldsymbol{B}$, Quantitative analysis of PH3-immunopositive nucleus density on SVZ and aRMS explants at 6 and $24 \mathrm{~h}$ in control condition and after HGF $(50 \mathrm{ng} / \mathrm{ml})$ treatment. Two-way ANOVA was used to compare groups ( ${ }^{* *} p<0.01,24 \mathrm{~h}$ vs $6 \mathrm{~h}$ for both (TR and HGF conditions). C, Quantification of the migration area calculated as the area occupied by SYTOX Green-positive nuclei outside SVZ or aRMS explants (aRMS: HGF vs CTR, ${ }^{*} p<0.05$, two-way ANOVA). D, Quantification of the migration area in aRMS explants. One-way ANOVA followed by the Bonferroni post hoc test was used to compare differences between treatments (HGF vs CTR, ${ }^{*} p<0.05$; HGF vs $\alpha H G F,{ }^{* *} p<0.01$ ). $\boldsymbol{E}$, aRMS explants stained with SYTOX Green at $1 \mathrm{DIV}$, in CTR, after HGF ( $50 \mathrm{ng} / \mathrm{ml})$, or after neutralizing anti-HGF antibody ( $\alpha \mathrm{HGF} ; 10 \mu \mathrm{g} / \mathrm{ml})$ along with HGF (50 $\mathrm{ng} / \mathrm{ml}) . \boldsymbol{F}, \mathbf{G}$, Cellular distribution of outwardly SYTOX Green-positive migrating cells showing the number of neuroblasts per unit of area that reach progressive distances from the border of aRMS explants at 1 DIV. Values are expressed as mean \pm SEM. Repeated-measures one-way ANOVA and the Bonferroni post hoc test were used to compare differences with control or with HGF treatment (HGF vs CTR and HGF vs $\alpha \mathrm{HGF},{ }^{* *} p<0.01$ ).

SVZ than in the aRMS $(p<0.01)$. According to $\mathrm{PH} 3$ results, no differences were observed in the density of Ki67-positive cells after HGF treatment in both SVZ and aRMS explants (Ki67positive cells $/ \mathrm{mm}^{2}$ : SVZ-CTR, $552.8 \pm 74.5$; SVZ-HGF, $548.1 \pm$ 67.8; aRMS-CTR, 223.8 \pm 35.5; aRMS-HGF, $264.1 \pm 42.4$ ), supporting the fact that treatment with exogenous HGF does not induce proliferative effects.

To assess whether HGF affects survival in this experimental system, we analyzed the expression of activated caspase-3, which has been shown to be implicated in programmed cell death (Srinivasan et al., 1998). Analysis was performed in SVZ and aRMS explants cultured for 6 and $24 \mathrm{~h}$ in Matrigel, in the absence or presence of $50 \mathrm{ng} / \mathrm{ml} \mathrm{HGF}$. Generally, the number of apoptotic cells in the tissue explant core increased over time, but no differ- ences were observed after HGF stimulation in both SVZ and aRMS (caspase-3positive cells $/ \mathrm{mm}^{2}$ after $6 \mathrm{~h}$ : SVZ-CTR, $18 \pm 2$; SVZ-HGF, $25 \pm 5$; aRMS-CTR, $13 \pm 3$; aRMS-HGF, $19 \pm 3$; caspase-3positive cells $/ \mathrm{mm}^{2}$ after $24 \mathrm{~h}$ : SVZ-CTR, $175 \pm 23$; SVZ-HGF, $150 \pm$ 9; aRMSCTR, $215 \pm 11$; aRMS-HGF, $197 \pm 19$ ).

\section{HGF promotes motility on RMS neuroblasts}

To evaluate a possible effect of HGF on neuroblast migration, explants cultured in Matrigel for $24 \mathrm{~h}$ were counterstained with SYTOX Green nucleic acid stain, and the area occupied by the cells migrated out of the explants, here referred to as "migration area," was quantified (see Materials and Methods for details).

An increase in the migration area was observed compared with control when HGF (50 ng/ml) was added to aRMS explants $(p<0.05)$ (Fig. 3C). In contrast, such an effect was not observed after HGF treatment on SVZ explants (Fig. 3C). Specificity of the HGF effect on aRMS neuroblast migration was confirmed by neutralizing anti-HGF antibody treatment $(10 \mu \mathrm{g} / \mathrm{ml})$ along with HGF. In this experimental condition, the migration area was indeed comparable with controls (Fig. $3 D, E)$. Moreover, there was no change in the area of the tissue explants between the experimental groups $(p>0.05$; CTR, $24.4 \pm 7.5 \times 10^{4} \mu \mathrm{m}^{2}$; HGF, $23.3 \pm 6.6 \times$

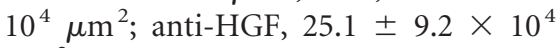
$\mu \mathrm{m}^{2}$ ).

To further investigate the HGF motogenic effect, we evaluated the distribution of cells within the migration area by quantifying the number of cells reaching progressive distances from the border of the explants (see also Materials and Methods) (Fig. $3 F, G$ ). Although the total number of migrated neuroblasts increased after HGF treatment (number of SYTOX-Greenpositive cells/area counted: CTR, $1589.1 \pm$ 129.9; HGF, $2490.6 \pm 135$; $\mathrm{HGF}+\alpha \mathrm{HGF}$, $1820 \pm 170.9$; CTR vs HGF, $p<0.001$; HGF vs HGF $+\alpha \mathrm{HGF}, p<0.01$ ), the cell distribution in the migration area was similar in all conditions (Fig. $3 F$ ). Statistically significant differences in cell density between HGF-treated and control explants were found at distance intervals up to $200 \mu \mathrm{m}$ from the explant border (Fig. $3 F)(p<0.01)$. These results suggest that HGF mainly acts by promoting motility on a larger number of cells, having no effect on the maximal distance they reach.

\section{HGF is a guidance signal for $\mathrm{OB}$ interneuron precursors}

In addition to the motogenic role, HGF could also play a chemotactic function, as documented by several studies in other neuronal migratory systems (Giacobini et al., 2002, 2007; Sun et al., 2002; Cacci et al., 2003). To verify the chemotactic activity of 
A

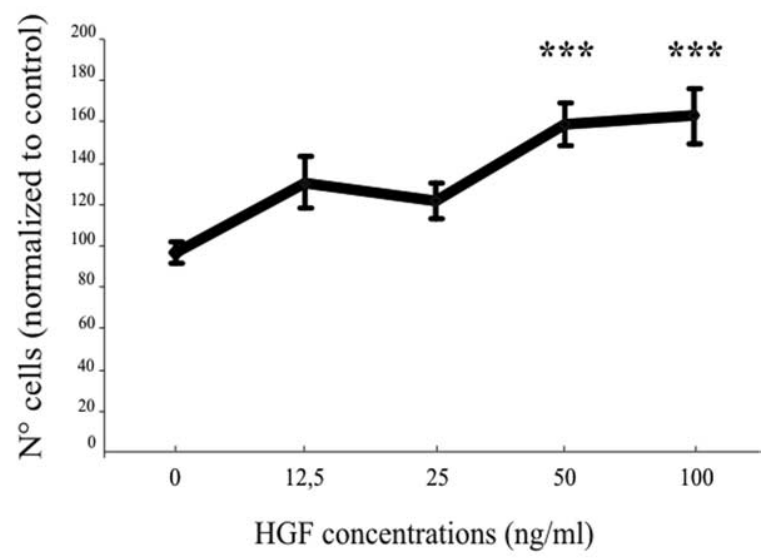

B

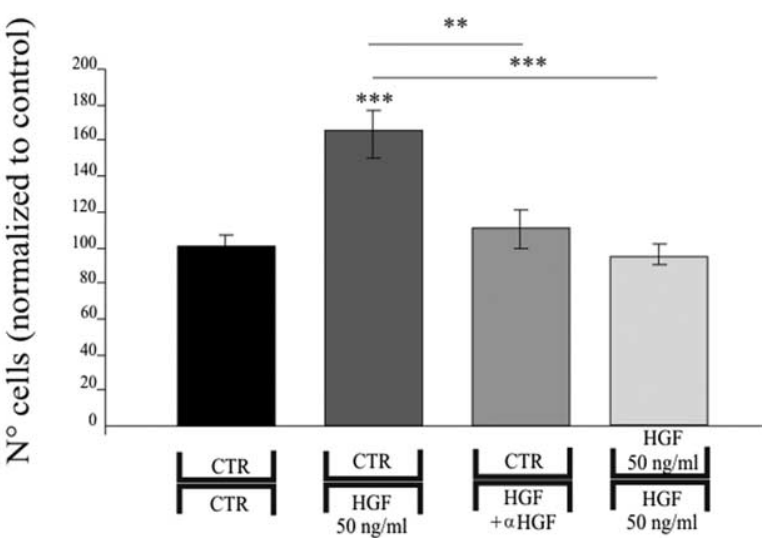

Figure 4. HGF is a chemoattractant for RMS neuroblasts. $A$, Boyden chamber dose-effect assay on freshly dissociated RMS cells. $\boldsymbol{B}$, Boyden chamber assay on RMS-derived cells in the presence of (TR medium in both chambers, in the presence of HGF $(50 \mathrm{ng} / \mathrm{ml})$ or neutralizing anti-HGF antibody $(\alpha \mathrm{HGF} ; 10 \mu \mathrm{g} / \mathrm{ml})$ along with HGF $(50 \mathrm{ng} / \mathrm{ml})$ in the lower chamber and (TR in the upper chamber, or HGF $(50 \mathrm{ng} / \mathrm{ml})$ in both upper and lower compartments. Data (mean \pm SEM) are presented as the total number of cells for each well normalized to control. One-way ANOVA followed by the Bonferroni post hoc test was used to compare groups $\left({ }^{* *} p<\right.$ $0.01 ; * * * 00.001)$.

HGF on OB interneuron precursors, we performed a Boyden chamber assay on freshly dissociated cells, isolated from the aRMS of postnatal mice. Addition of HGF to the lower compartment of the chamber only establishes a concentration gradient. After $24 \mathrm{~h}$, the migrated cells were stained with the nuclear marker DAPI and counted. The neuronal nature of these cells was checked by immunocytochemical analysis using anti- $\beta$ IIItubulin antibody. This analysis showed that virtually all DAPIpositive nuclei belong to neuronal cells (supplemental Fig. 3, available at www.jneurosci.org as supplemental material). The number of migrated neuroblasts increased in a dose-dependent manner after HGF treatment at different concentrations, with maximal effect at concentrations of 50 and $100 \mathrm{ng} / \mathrm{ml}$ (Fig. 4A). At $50 \mathrm{ng} / \mathrm{ml}$, the migratory effect was 1.5 -fold compared with control conditions $(p<0.01)$ (Fig. $4 B)$. When the concentration gradient was abolished by adding HGF ( $50 \mathrm{ng} / \mathrm{ml}$ ) to both the upper and lower compartments of the chamber, the number of cells that had migrated to the lower side of the membrane decreased to values similar to controls. Similarly, incubation with
HGF preadsorbed with the anti-HGF antibody completely abolished the HGF-induced response (Fig. $4 B$ ), further confirming a specific chemotactic effect of exogenous HGF on interneuron precursors.

Met-Grb2 binding is necessary for RMS neuroblast migration A wide range of signaling players involved in cell motility induced by HGF has been identified (Sachs et al., 2000; Schaeper et al., 2000). In particular, it has recently been demonstrated that the PI-3-kinase/AKT and MAP kinase pathways are implicated in the promigratory effects of HGF on cortical neurons (Segarra et al., 2006). To ascertain whether these two signaling pathways are also activated by HGF in the RMS, we performed acute treatments with HGF on freshly dissected RMS explants. After 15 min of stimulation, the level of AKT phosphorylation was comparable with the control condition, indicating that the PI-3-K/AKT signaling is not activated by HGF in this system (Fig. 5A). On the contrary, the same HGF stimulation induced a twofold increase of ERK protein phosphorylation (Fig. 5B). ERKs activation was abolished when explants were treated with HGF in the presence of the specific MAP kinase pathway inhibitor PD98059 (50 $\mu \mathrm{M})$ (Fig. 5B). Met receptor can activate the MAP kinase cascade directly through the Grb2 binding site (Ponzetto et al., 1996). $M e t^{G r b 2 / G r b 2}$ mutants were generated by knocking in the Met locus a point mutation that interferes with the binding of the Grb2 adapter to the receptor, thus impairing its ability to activate the Ras/MAP kinase signaling, while all other effectors are still able to bind (Maina et al., 1996). Mutation of the Met-Grb2 binding site affects postnatal viability, probably because of respiratory problems (Maina et al., 1996). In newborn mutants, the macroscopic anatomy and layer organization of the $\mathrm{OB}$ did not significantly differ from the wild-type controls (our personal observations). To investigate whether the Ras/MAP kinase cascade is impaired along the SVZ-OB system in these mice, RMS explants microdissected from P0 mutant and wild-type mice were treated for 20 min with HGF. Activation of the Ras/MAP kinase pathway was then assessed by evaluating phosphorylation of the downstream ERK effectors by Western blot analysis. As a positive control, RMS explants both from mutants and wild-type animals were also treated with BDNF, which had previously been demonstrated to activate MAP kinase pathway in this system (Chiaramello et al., 2007). Densitometric analysis of the blots showed that HGF stimulation induces a twofold increase in ERK phosphorylation in wild-type animals, whereas in tissue explants obtained from $M e t^{G r b 2 / G r b 2}$ mutants, the level of ERK phosphorylation did not change after HGF treatment (Fig. 5C). Conversely, the pattern of BDNF-induced ERK phosphorylation is similar in wild-type and mutant RMS explants (Fig. 5C). These data indicate that in $\mathrm{Met}^{\mathrm{Grb2} / \mathrm{Grb2}}$ mice, HGF-mediated activation of the Ras/MAP kinase cascade is impaired. Because this effect is specific for HGF stimulation, it must be a consequence of the mutated Met protein and likely to be caused by the loss of the Grb2binding site. Because these homozygous mutant mice die soon after birth, functional analyses were performed in vitro on RMS explants of P0 Met ${ }^{G r b 2 / G r b 2}$ and wild-type animals cultured in Matrigel. At 1 DIV, the migration area of explants obtained from $M e t^{G r b 2 / G r b 2}$ mutants is reduced compared with wild-type (WT, $100 \pm 5 ; n=63$ out of 3 animals; $\mathrm{Met}^{\mathrm{Grb2/Grb2}}, 71 \pm 4 ; n=99$ out of 3 animals; $p<0.001, t$ test) (Fig. $5 D$ ), indicating that a full $\mathrm{HGF} / \mathrm{Met}$ signaling is necessary for RMS neuroblast migration.

Because HGF-induced MAP kinase cascade activation had been demonstrated to trigger a proliferation response in other brain regions (Ieraci et al., 2002; Kuhlmann et al., 2005), the 


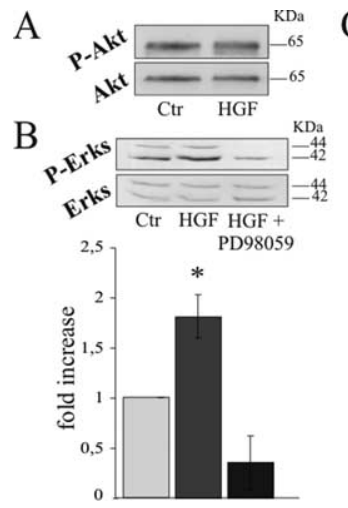

$\mathrm{C}$
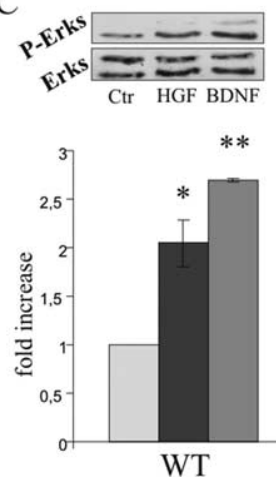

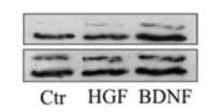

$\mathrm{D}$

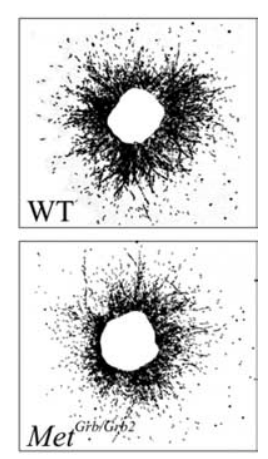

Figure 5. Uncoupling Met-Grb2 signaling impairs RMS neuroblast migration. $A$, Western blot analysis for AKT and AKT phosphorylation on freshly dissociated RMS explants in (TR and after a $15 \mathrm{~min} \mathrm{HGF}$ treatment ( $50 \mathrm{ng} / \mathrm{ml})$. Densitometric analysis: $\mathrm{CTR}=1 ; \mathrm{HGF}=1.1 \pm 0.0003 ; n=3 ; p>0.05, t$ test. $\boldsymbol{B}$, Western blot analysis for ERK phosphorylation on freshly dissociated RMS explants in CTR, after a 15 min treatment with HGF ( $50 \mathrm{ng} / \mathrm{ml})$ alone or in the presence of the MAP kinase inhibitor PD98059 $(50 \mu \mathrm{M})$. Data on phosphorylated ERKs were normalized against ERK expression levels. Histograms show mean \pm SEM obtained from three independent experiments. One-way ANOVA followed by least significant difference (LSD) post hoc test (for ERK phosphorylation) was used to compare groups $\left({ }^{*} p<0.05\right)$. C, Western blot analysis on extracts of RMS explants from PO WT and Met ${ }^{6 r b 2 / / 6 r b 2}$ mutant mice, stimulated with HGF (50 ng/ml) or BDNF ( $\left.20 \mathrm{ng} / \mathrm{ml}\right)$ for $20 \mathrm{~min}$. Blots were probed with anti-phosphoERKs, stripped, and reprobed with an antibody against total MAP kinase for normalization. Histograms show densitometric analysis. Values were obtained from three independent experiments and are presented as mean \pm SEM. Two-way ANOVA was used to compare groups, followed by LSD post hoc test $\left({ }^{*} p<0.05\right.$, WT-CTR vs WT-HGF; ${ }^{* *} p<0.01$, WT-CTR vs WT-BDNF and Met $^{G \mathrm{Grb2} / \mathrm{Grb2}}$-CTR vs Met ${ }^{\mathrm{Grb2} / \mathrm{Grb2}}$-BDNF). D, RMS explants at 1 DIV stained with SYTOX Green, in CTR, of WT and Met ${ }^{\mathrm{Grb2} / \mathrm{Grb2} 2} \mathrm{P} 0$ mice.

mitogenic activity was examined in RMS tissue explants at 1 DIV. No differences were observed in the density of Ki67-positive cells between wild-type and $\mathrm{Met}^{\mathrm{Grb2/Grb2}}$-derived explants (WT, $100 \pm$ $11 ; n=16$ out of 2 animals; Met ${ }^{\mathrm{Grb} 2 / \mathrm{Gr} b 2}, 82 \pm 9 ; n=25$ out of 2 animals; $p>0.05, t$ test), supporting the fact that HGF signaling through Met-Grb2 binding does not influence proliferation in this system. We can thus affirm that the reduced migration observed in these mice is not influenced by a mitogenic defect.

\section{Discussion}

The migration of olfactory interneuron precursors from the SVZ toward the $\mathrm{OB}$ is a highly regulated process influenced by different factors, including soluble molecules with attractive or repulsive functions as well as cell adhesion and extracellular matrix molecules (Ono et al., 1994; Hu et al., 1996; Wu et al., 1999; Conover et al., 2000; Menezes et al., 2002). In this report, we provided evidence that HGF and its receptor Met are likely to be involved in this process. First, we showed that they are expressed in a spatial pattern to impact olfactory precursor migration. As in previous studies (Honda et al., 1995; Thewke and Seeds, 1996; Achim et al., 1997), we found HGF transcript expression in the RMS and expression of both HGF and Met transcripts in the OB. Moreover, we demonstrated for the first time the occurrence of biologically active HGF all along the system from the SVZ to the OB. In addition, our RT-PCR and Western blot results showed Met expression along the migratory pathway. These findings were further confirmed by immunocytochemistry performed on tissue explants cultured in vitro, which clearly showed Met localization in PSA-N-CAM-immunopositive migrating neuroblasts, strongly supporting a role for HGF/Met signaling in the biology of these cells. Immunocytochemistry also revealed that Met is not expressed by GFAP-positive astrocytes in RMS-derived explants, supporting the fact that HGF acts directly on neuroblasts along the RMS.

HGF activity requires proteolytic processing and the release from sequestration sites in the extracellular matrix, which are, at least partially, operated through enzymatic cleavage by plasmin- ogen activators (Naldini et al., 1992; Matsuoka et al., 2006). Previous in situ hybridization data (Thewke et al., 1996) and our RT-PCR analysis (our personal observations) indicated expression of the tissue plasminogen activator along the postnatal RMS and OB. These data, although only correlative, suggest that the SVZ-OB system has the molecular machinery to activate HGF in the immediate vicinity of its Met receptor. Accordingly, Western blot analysis on freshly dissected tissue explants showed that Met receptor is activated along the migratory pathway. We also showed that treatments with exogenous HGF on RMS tissue explants increase Met phosphorylation, indicating that HGF is able to further activate its receptor, most likely exerting a biological effect on this cellular system.

HGF is a target-derived chemotropic factor for different migratory systems, including cortical interneurons, striatal progenitors, and GnRH neurons (Powell et al., 2001; Giacobini et al., 2002, 2007; Cacci et al., 2003). The OB plays an attracting role on RMS neuroblasts, and the glomerular and mitral cell layers seem to be relevant to this activity (Liu and Rao, 2003). Interestingly, previous in situ hybridization studies demonstrated HGF mRNA expression in the glomerular layer (Thewke and Seeds, 1996), and our Western blot analysis indicated the occurrence of mature HGF in extracts from the whole $\mathrm{OB}$, supporting its function as a chemoattractant in vivo. Thus, to evaluate whether HGF acts as a guidance cue for olfactory interneuron precursors, we used a Boyden chamber assay performed on freshly dissociated RMS precursors under HGF stimulation. We observed that these cells significantly respond to HGF chemotactic stimulus in a dose-related manner. In addition to the chemotactic effect, experiments performed treating RMS tissue explants with exogenous HGF also indicated a motogenic effect. Quantitative assessment of neuronal migration revealed a significant increase, by HGF exposure, of neuroblasts migrating out of the tissue explants. Although Met receptor is expressed along the entire migratory pathway, from the SVZ to the OB core, our in vitro analysis indicated that HGF motogenic effect is restricted to the RMS, whereas no motogenic effect was observed on tissue explants deriving from the SVZ. The activity of guidance cues can be modulated by interactions with other extracellular and/or intracellular signals, indicating that the action of motogenic factors could be context dependent (Mason et al., 2001; Paratcha et al., 2006). Therefore, the differential migratory response of neuroblasts to HGF stimulation in the SVZ and RMS could result from the activation of different signaling pathways or from the activation of different molecular mediators. Interestingly, $\beta 1$ integrin subunit, which regulates HGF cell invasiveness through cell-matrix interactions (Trusolino et al., 2000; Zhang et al., 2003; Hebrok and Reichardt, 2004), is unevenly distributed along the system (being more expressed in the RMS than in the SVZ) (Belvindrah et al., 2007), suggesting that molecules differentially expressed along the migratory pathway might act synergically with HGF influencing its activity.

HGF is a pleiotropic factor that plays multiple functions during brain development, including regulation of the cell cycle of 
embryonic neural stem cells (Kokuzawa et al., 2003), proliferation of cerebellar granule cells (Ieraci et al., 2002), and survival of sensory and motoneurons (Ebens et al., 1996; Maina et al., 1997). The HGF concentration used in this assay $(50 \mathrm{ng} / \mathrm{ml})$ is known to induce cell proliferation in different cell systems (Wang et al., 2004). Thus, we wondered whether HGF could exert other functions in this system in addition to the promigratory effect. In vivo, the SVZ of the lateral ventricle is enriched by stem cells and proliferating progenitors. In contrast, it has been previously shown that the RMS contains only a reduced number of stem cells and proliferating cells (Gritti et al., 2002), whereas it is highly enriched in migrating neuroblasts. The main effect of HGF observed in this study was an increase in cell migration in RMS explants. Indeed, no differences in the number of proliferating cells were observed in the SVZ nor in the RMS, suggesting that, at least in our experimental conditions, HGF does not exert a mitogenic effect. These observations are in agreement with previous studies on striatal (Cacci et al., 2003) and cortical (Sun et al., 2002) progenitors showing that HGF plays solely a motogenic role without affecting cell proliferation.

Quantitative analysis of cleaved-caspase-3-immunopositive cells on SVZ and RMS explants at different culture times were performed to investigate whether HGF can act as an antiapoptotic factor in this system. Results obtained suggested that HGF does not influence cell survival in our experimental conditions.

Lack of motogenic, mitogenic, and anti-apoptotic effects reported for HGF on SVZ explants does not rule out other possible alternative functions on SVZ stem cells, such as staminal niche maintenance (Sun et al., 2002; Kokuzawa et al., 2003), which will require additional investigations.

Early embryonic lethality of met and HGF knock-out animals (Schmidt et al., 1995; Uehara et al., 1995) prevented studies on these mice to determine the functional role of HGF in the SVZ-OB system. In this study, to investigate more closely the promigratory function of HGF on olfactory interneuron precursors, we used a knock-in mouse with a point mutation in the Met receptor that impairs signal transduction through the Ras/MAP kinase pathway (Met $t^{G r b 2 / G r b 2}$ ) (Maina et al., 1996). Indeed, our analysis on the downstream signaling pathway indicated that HGF triggers MAP kinase, but not PI-3-kinase, activation on RMS tissue explants. As shown by our experiments and in other cellular systems (Fixman et al., 1995; Maina et al., 1996; Ponzetto et al., 1996; Besser et al., 1997; Ieraci et al., 2002), Met ${ }^{\mathrm{Grb2} / \mathrm{Grb2}}$ animals have a mutation of the Met-Grb2 binding site that impairs MAP kinase activation after HGF stimulation. These mutants die almost invariably several hours after birth (Maina et al., 1996), making it impossible to trace neuronal migration through classical BrdU injections or cell-tracing in vivo. We thus analyzed the migratory behavior of neuroblasts in RMS explants generated from newborn animals. The migration area in $\mathrm{Met}^{\mathrm{Grb} 2 / \mathrm{Grb2}}$ derived explants is significantly reduced compared with wildtype animals. These results support the fact that endogenous HGF produced by tissue explants exerts a motogenic effect on RMS neuroblasts and that this activity is affected by the Grb2directed mutation, indicating a role for Met/Grb2-mediated signaling for normal neuroblast migration. As expected, because of the large cohort of molecular factors controlling neuronal migration, the motility of RMS neuroblasts was only partially impaired in $\mathrm{Met}^{\mathrm{Grb2} / \mathrm{Grb2}}$ tissue explants. Moreover, this Met mutation confers only a partial loss of function (Maina et al., 1996), and we cannot exclude the involvement of other HGF-activated intracellular pathways, such as Shc, phospholipase C $\gamma$, SHP2, and Gab1 signaling, that are not altered in $\mathrm{Met}^{\mathrm{Grb2/Grb2}}$ mice (Pelicci et al., 1995; Fournier et al., 1996; Ponzetto et al., 1996; Sachs et al., 2000; Schaeper et al., 2000). Interestingly, we observed no differences in the proliferation activity comparing tissue explants obtained from the RMS of wild-type or mutant mice, further supporting the fact that a mitogenic effect of HGF on RMS neuroblasts is unlikely.

Overall, our data, gathered from experiments on primary in vitro tissue cultures and analysis of a partial loss-of-function Met knock-in mouse, indicate that HGF is involved in the regulation of neuroblast migration along the RMS and toward the OB. Our results suggest that the Met receptor most likely mediates this effect by Grb2 recruitment.

\section{References}

Achim CL, Katyal S, Wiley CA, Shiratori M, Wang G, Oshika E, Petersen BE, Li JM, Michalopoulos GK (1997) Expression of HGF and cMet in the developing and adult brain. Brain Res Dev Brain Res 102:299-303.

Alvarez-Buylla A, Garcia-Verdugo JM (2002) Neurogenesis in adult subventricular zone. J Neurosci 22:629-634.

Belvindrah R, Hankel S, Walker J, Patton BL, Muller U (2007) $\beta 1$ integrins control the formation of cell chains in the adult rostral migratory stream. J Neurosci 27:2704-2717.

Besser D, Bardelli A, Didichenko S, Thelen M, Comoglio PM, Ponzetto C, Nagamine Y (1997) Regulation of the urokinase-type plasminogen activator gene by the oncogene Tpr-Met involves GRB2. Oncogene 14:705-711.

Birchmeier C, Gherardi E (1998) Developmental roles of HGF/SF and its receptor, the c-Met tyrosine kinase. Trends Cell Biol 8:404-410.

Bovetti S, Bovolin P, Perroteau I, Puche AC (2007) Subventricular zonederived neuroblast migration to the olfactory bulb is modulated by matrix remodelling. Eur J Neurosci 25:2021-2033.

Cacci E, Salani M, Anastasi S, Perroteau I, Poiana G, Biagioni S, AugustiTocco G (2003) Hepatocyte growth factor stimulates cell motility in cultures of the striatal progenitor cells ST14A. J Neurosci Res 74:760-768.

Chan AM, King HW, Deakin EA, Tempest PR, Hilkens J, Kroezen V, Edwards DR, Wills AJ, Brookes P, Cooper CS (1988) Characterization of the mouse met proto-oncogene. Oncogene 2:593-599.

Chiaramello S, Dalmasso G, Bezin L, Marcel D, Jourdan F, Peretto P, Fasolo A, De Marchis S (2007) BDNF/ TrkB interaction regulates migration of SVZ precursor cells via PI3-K and MAP-K signalling pathways. Eur J Neurosci 26:1780-1790.

Conover JC, Doetsch F, Garcia-Verdugo JM, Gale NW, Yancopoulos GD, Alvarez-Buylla A (2000) Disruption of Eph/ephrin signaling affects migration and proliferation in the adult subventricular zone. Nat Neurosci 3:1091-1097.

Ebens A, Brose K, Leonardo ED, Hanson Jr MG, Bladt F, Birchmeier C, Barres BA, Tessier-Lavigne M (1996) Hepatocyte growth factor/scatter factor is an axonal chemoattractant and a neurotrophic factor for spinal motor neurons. Neuron 17:1157-1172.

Estivill-Torrus G, Pearson H, van Heyningen V, Price DJ, Rashbass P (2002) Pax6 is required to regulate the cell cycle and the rate of progression from symmetrical to asymmetrical division in mammalian cortical progenitors. Development 129:455-466.

Fixman ED, Naujokas MA, Rodrigues GA, Moran MF, Park M (1995) Efficient cell transformation by the Tpr-Met oncoprotein is dependent upon tyrosine 489 in the carboxy-terminus. Oncogene 10:237-249.

Fournier TM, Kamikura D, Teng K, Park M (1996) Branching tubulogenesis but not scatter of Madin-Darby canine kidney cells requires a functional Grb2 binding site in the Met receptor tyrosine kinase. J Biol Chem 271:22211-22217.

Giacobini P, Giampietro C, Fioretto M, Maggi R, Cariboni A, Perroteau I, Fasolo A (2002) Hepatocyte growth factor/scatter factor facilitates migration of GN-11 immortalized LHRH neurons. Endocrinology 143:3306-3315.

Giacobini P, Messina A, Wray S, Giampietro C, Crepaldi T, Carmeliet P, Fasolo A (2007) Hepatocyte growth factor acts as a motogen and guidance signal for gonadotropin hormone-releasing hormone-1 neuronal migration. J Neurosci 27:431-445.

Gritti A, Bonfanti L, Doetsch F, Caille I, Alvarez-Buylla A, Lim DA, Galli R, 
Verdugo JM, Herrera DG, Vescovi AL (2002) Multipotent neural stem cells reside into the rostral extension and olfactory bulb of adult rodents. J Neurosci 22:437-445.

Hara H, Nakae Y, Sogabe T, Ihara I, Ueno S, Sakai H, Inoue H, Shimizu S, Nakamura T, Shimizu N (1993) Structural study of the N-linked oligosaccharides of hepatocyte growth factor by two-dimensional sugar mapping. J Biochem (Tokyo) 114:76-82.

Hebrok M, Reichardt LF (2004) Brain meets pancreas: netrin, an axon guidance molecule, controls epithelial cell migration. Trends Cell Biol 14:153-155.

Honda S, Kagoshima M, Wanaka A, Tohyama M, Matsumoto K, Nakamura T (1995) Localization and functional coupling of HGF and c-Met/HGF receptor in rat brain: implication as neurotrophic factor. Brain Res Mol Brain Res 32:197-210.

Hu H, Tomasiewicz H, Magnuson T, Rutishauser U (1996) The role of polysialic acid in migration of olfactory bulb interneuron precursors in the subventricular zone. Neuron 16:735-743.

Ieraci A, Forni PE, Ponzetto C (2002) Viable hypomorphic signaling mutant of the Met receptor reveals a role for hepatocyte growth factor in postnatal cerebellar development. Proc Natl Acad Sci USA 99:15200-15205.

Jankovski A, Sotelo C (1996) Subventricular zone-olfactory bulb migratory pathway in the adult mouse: cellular composition and specificity as determined by heterochronic and heterotopic transplantation. J Comp Neurol 371:376-396

Jung W, Castren E, Odenthal M, Vande Woude GF, Ishii T, Dienes HP, Lindholm D, Schirmacher P (1994) Expression and functional interaction of hepatocyte growth factor-scatter factor and its receptor c-met in mammalian brain. J Cell Biol 126:485-494.

Kokuzawa J, Yoshimura S, Kitajima H, Shinoda J, Kaku Y, Iwama T, Morishita R, Shimazaki T, Okano H, Kunisada T, Sakai N (2003) Hepatocyte growth factor promotes proliferation and neuronal differentiation of neural stem cells from mouse embryos. Mol Cell Neurosci 24:190-197.

Kuhlmann CR, Schaefer CA, Fehsecke A, Most AK, Tillmanns H, Erdogan A (2005) A new signaling mechanism of hepatocyte growth factor-induced endothelial proliferation. J Thromb Haemost 3:2089-2095.

Liu G, Rao Y (2003) Neuronal migration from the forebrain to the olfactory bulb requires a new attractant persistent in the olfactory bulb. J Neurosci 23:6651-6659.

Lois C, Alvarez-Buylla A (1994) Long-distance neuronal migration in the adult mammalian brain. Science 264:1145-1148.

Luskin MB (1993) Restricted proliferation and migration of postnatally generated neurons derived from the forebrain subventricular zone. Neuron 11:173-189.

Maina F, Casagranda F, Audero E, Simeone A, Comoglio PM, Klein R, Ponzetto C (1996) Uncoupling of Grb2 from the Met receptor in vivo reveals complex roles in muscle development. Cell 87:531-542.

Maina F, Hilton MC, Ponzetto C, Davies AM, Klein R (1997) Met receptor signaling is required for sensory nerve development and HGF promotes axonal growth and survival of sensory neurons. Genes Dev 11:3341-3350.

Mason HA, Ito S, Corfas G (2001) Extracellular signals that regulate the tangential migration of olfactory bulb neuronal precursors: inducers, inhibitors, and repellents. J Neurosci 21:7654-7663.

Matsuoka H, Sisson TH, Nishiuma T, Simon RH (2006) Plasminogenmediated activation and release of hepatocyte growth factor from extracellular matrix. Am J Respir Cell Mol Biol 35:705-713.

Menezes JR, Marins M, Alves JA, Froes MM, Hedin-Pereira C (2002) Cell migration in the postnatal subventricular zone. Braz J Med Biol Res 35:1411-1421.

Murase S, Horwitz AF (2002) Deleted in colorectal carcinoma and differentially expressed integrins mediate the directional migration of neural precursors in the rostral migratory stream. J Neurosci 22:3568-3579.

Naldini L, Tamagnone L, Vigna E, Sachs M, Hartmann G, Birchmeier W, Daikuhara Y, Tsubouchi H, Blasi F, Comoglio PM (1992) Extracellular proteolytic cleavage by urokinase is required for activation of hepatocyte growth factor/scatter factor. EMBO J 11:4825-4833.

Ng KL, Li JD, Cheng MY, Leslie FM, Lee AG, Zhou QY (2005) Dependence of olfactory bulb neurogenesis on prokineticin 2 signaling. Science 308:1923-1927.

Ono K, Tomasiewicz H, Magnuson T, Rutishauser U (1994) N-CAM mutation inhibits tangential neuronal migration and is phenocopied by enzymatic removal of polysialic acid. Neuron 13:595-609.

Paratcha G, Ibanez CF, Ledda F (2006) GDNF is a chemoattractant factor for neuronal precursor cells in the rostral migratory stream. Mol Cell Neurosci 31:505-514.

Pelicci G, Giordano S, Zhen Z, Salcini AE, Lanfrancone L, Bardelli A, Panayotou G, Waterfield MD, Ponzetto C, Pelicci PG, Comoglio PM (1995) The motogenic and mitogenic responses to HGF are amplified by the Shc adaptor protein. Oncogene 10:1631-1638.

Peretto P, Merighi A, Fasolo A, Bonfanti L (1997) Glial tubes in the rostral migratory stream of the adult rat. Brain Res Bull 42:9-21.

Peretto P, Merighi A, Fasolo A, Bonfanti L (1999) The subependymal layer in rodents: a site of structural plasticity and cell migration in the adult mammalian brain. Brain Res Bull 49:221-243.

Ponzetto C, Zhen Z, Audero E, Maina F, Bardelli A, Basile ML, Giordano S, Narsimhan R, Comoglio P (1996) Specific uncoupling of GRB2 from the Met receptor. Differential effects on transformation and motility. J Biol Chem 271:14119-14123.

Powell EM, Mars WM, Levitt P (2001) Hepatocyte growth factor/scatter factor is a motogen for interneurons migrating from the ventral to dorsal telencephalon. Neuron 30:79-89.

Radovick S, Wray S, Lee E, Nicols DK, Nakayama Y, Weintraub BD, Westphal H, Cutler Jr GB, Wondisford FE (1991) Migratory arrest of gonadotropinreleasing hormone neurons in transgenic mice. Proc Natl Acad Sci USA 88:3402-3406.

Sachs M, Brohmann H, Zechner D, Muller T, Hulsken J, Walther I, Schaeper U, Birchmeier C, Birchmeier W (2000) Essential role of Gabl for signaling by the c-Met receptor in vivo. J Cell Biol 150:1375-1384.

Schaeper U, Gehring NH, Fuchs KP, Sachs M, Kempkes B, Birchmeier W (2000) Coupling of Gab1 to c-Met, Grb2, and Shp2 mediates biological responses. J Cell Biol 149:1419-1432.

Schmidt C, Bladt F, Goedecke S, Brinkmann V, Zschiesche W, Sharpe M, Gherardi E, Birchmeier C (1995) Scatter factor/hepatocyte growth factor is essential for liver development. Nature 373:699-702.

Segarra J, Balenci L, Drenth T, Maina F, Lamballe F (2006) Combined signaling through ERK, PI3K/AKT, and RAC1/p38 is required for mettriggered cortical neuron migration. J Biol Chem 281:4771-4778.

Srinivasan A, Roth KA, Sayers RO, Shindler KS, Wong AM, Fritz LC, Tomaselli KJ (1998) In situ immunodetection of activated caspase-3 in apoptotic neurons in the developing nervous system. Cell Death Differ 5:1004-1016.

Sun W, Funakoshi H, Nakamura T (2002) Localization and functional role of hepatocyte growth factor (HGF) and its receptor c-met in the rat developing cerebral cortex. Brain Res Mol Brain Res 103:36-48.

Tashiro K, Hagiya M, Nishizawa T, Seki T, Shimonishi M, Shimizu S, Nakamura T (1990) Deduced primary structure of rat hepatocyte growth factor and expression of the mRNA in rat tissues. Proc Natl Acad Sci USA 87:3200-3204.

Thewke DP, Seeds NW (1996) Expression of hepatocyte growth factor/scatter factor, its receptor, c-met, and tissue-type plasminogen activator during development of the murine olfactory system. J Neurosci 16:6933-6944.

Tomasiewicz H, Ono K, Yee D, Thompson C, Goridis C, Rutishauser U, Magnuson T (1993) Genetic deletion of a neural cell adhesion molecule variant (N-CAM-180) produces distinct defects in the central nervous system. Neuron 11:1163-1174.

Trusolino L, Cavassa S, Angelini P, Ando M, Bertotti A, Comoglio PM, Boccaccio C (2000) HGF/scatter factor selectively promotes cell invasion by increasing integrin avidity. FASEB J 14:1629-1640.

Uehara Y, Minowa O, Mori C, Shiota K, Kuno J, Noda T, Kitamura N (1995) Placental defect and embryonic lethality in mice lacking hepatocyte growth factor/scatter factor. Nature 373:702-705.

Wang R, Yashpal N, Bacchus F, Li J (2004) Hepatocyte growth factor regulates proliferation and differentiation of epithelial monolayers derived from islets of postnatal rat pancreas. J Endocrinol 183:163-171.

Wichterle H, Garcia-Verdugo JM, Alvarez-Buylla A (1997) Direct evidence for homotypic, glia-independent neuronal migration. Neuron 18:779-791.

Wojtowicz JM, Kee N (2006) BrdU assay for neurogenesis in rodents. Nat Protoc 1:1399-1405.

Wu W, Wong K, Chen J, Jiang Z, Dupuis S, Wu JY, Rao Y (1999) Directional guidance of neuronal migration in the olfactory system by the protein Slit. Nature 400:331-336.

Zhang H, Ozaki I, Mizuta T, Yoshimura T, Matsuhashi S, Hisatomi A, Tadano J, Sakai T, Yamamoto K (2003) Mechanism of beta 1-integrin-mediated hepatoma cell growth involves p27 and S-phase kinase-associated protein 2. Hepatology 38:305-313. 